\title{
Wearable Technology in Education to Enhance Technical MOOCs
}

\author{
Siti Feirusz Ahmad Fesol ${ }^{\#}$, Sazilah Salam", Norasiken Bakar ${ }^{\#}$ \\ ${ }^{\#}$ Pervasive Computing \& Educational Technology (PET), Center for Advanced Computing Technology, Faculty of Information and \\ Communication Technology, Universiti Teknikal Malaysia Melaka, Hang Tuah Jaya, 76100 Durian Tunggal, Melaka, Malaysia \\ E-mail:feyrs88@gmail.com ${ }^{1}$, sazilah@utem.edu.my ${ }^{2}$,norasiken@utem.edu.my ${ }^{3}$
}

\begin{abstract}
The low completion rate issue in MOOCs has become one of the main highlights by researchers. It is reported that only 10 to 15 percent of the students were able to complete the MOOCs. This low completion rate is due to the students are less engaged with the MOOCs content causing them to become demotivated to complete the whole MOOCs. Engaging students in MOOCs environment, especially for non-technical subjects, suited very well. However, for technical MOOCs, it involves significant challenges because technical MOOCs must be able to offer the students with practice-oriented learning outcome in-order for the MOOCs to be effective and engaging. Due to the above issue, this paper discussed an improvised MOOCs model for teaching technical subjects with the intervention in the use of wearable technology. A discussion on the e-content and e-activity of the technical MOOC learning design was presented. This study implemented the proposed technical MOOC model through the MOOC development. The students' perception of the technical MOOC was then evaluated, and all the results were explained in the discussion part. Results of the correlation test revealed that all of the technical MOOC variables correlated substantially and held a positive relationship with students' perception variable with $r=.3$ to $1.0, p<.0005$. In addition, this result also suggests that the learning materials produced by wearable technology do contribute towards the positive effect of students' perception when learning technical MOOC.
\end{abstract}

Keywords - technical MOOC; wearable technology; smart glass; science MOOC; MOOC design.

\section{INTRODUCTION}

Online learning has become one of the fastest growing trends in educational fields [1]. MOOC or Massive Open Online Course is one of the online learning platforms. Hew [2] highlighted that the main purpose of online learning courses nowadays is to provide flexibility to access and manage the learning process as preferred by its learners and at the same time can reduce the learning cost. MOOC is a tuition course taught over the Internet that allows anyone to attend the course, and most of the courses offered are for free [3]. As reported by MoocLab, up until the end of December 2017 there were more than 17,000 courses offered with more than $100,000,000$ students enrolment from more than 800 universities, through 57 MOOC platforms and were adopted by more than 23 countries all over the world [4]. In addition, the learning environment offered by MOOC platform can support lifelong learning environment as it allows access to learning materials at any time and from anywhere [5]. The courses offered cover all education fields which can be categorized into technical courses particularly the science, technology, engineering, and Mathematics (the STEM fields); and non-technical courses particularly the humanities and social science fields. MOOCs' role does not design to replace the conventional classroom teaching system, but it is more to expanding the educational scopes, both for a new generation of learners and to users who desire to learn in new ways. Recent trends in MOOCs have led to the explosion of research in MOOCs environment which discussed the improvement in the model, framework, pedagogy, and course structure which the key objective is to promote an effective and engaging online learning [1]-[3], [6], [7]. However, one of the key concern of MOOCs as reported by [2] and [8] in their study is the high learners' dropout rate. These studies also highlighted several sources indicating that about 10 to 15 percent of MOOCs participants can complete the courses on average [9], [10]. The low completion rate of MOOC is a result of a lack of enthusiasm for the course engagement to motivate learners toward participation. Underpinning MOOC high dropout rate and retention issue, few solutions were suggested by previous studies to improve the MOOC in the pedagogical criteria [6], [11], [12], technical criteria [12], [13]. This research also includes additional engaging online elements, such as gamification [3], [14]-[16], social feedback [17], [18], and animation [19]-[21] in order to engage and motivate the students more towards the learning process.

A study by Anant Vaibhav and Puneet Gupta [14] suggested the inclusion of gamification elements in the MOOC structure to increase student's participation and student's engagement. In their research, they shared that in 
order to improve the retention of students throughout the MOOC course, it is necessary to make the MOOC platform more exciting and interactive for the students. Thus, one of the promising approaches to increase student's participation by applying gamification method specifically game design elements for non-game learning MOOC contents [14]. Other studies also highlighted the gamification effects of MOOCs and proposed a model based on game elements in order to improve learners' engagement and motivation [15], [16].

Exploring further, Venture et al. [17] discovered the implementation of social media as a complementary with Professional English MOOC course. The students are encouraged to express their thoughts, rating and commenting on others' contribution and helping other students on their use of English using social media platform [17]. Another interesting study in the used of social media with MOOC was conducted by [18] where the study integrated customized social software platform to deliver the MOOC course. The study concluded that the proposed MOOC was able to support peer-peer interactions via integrated social media tools and techniques, and was able to offer an openaccess personal learning experience in order to engage the student [18].

Engaging students in MOOCs environment especially for non-technical subjects, suit very well. However, for technical MOOCs, it involved significant challenges because technical MOOCs must able to offer practice-oriented learning in order for the MOOCs to be effective and engaging [5], [13], [22], [23]. In this context, few researchers suggested the inclusion of remote laboratory [5], [13] and wearable technology [24], [25] as an alternative to engaging the students more with the MOOCs. Given the exciting developments offered by wearable technology, researchers believed that wearable technology has enormous potential implication and benefits especially for augmentation reality environments in supporting education by some potential advantages. Firstly, wearable technology can motivate, stimulate, and engage students in exploring learning materials from different perspectives. Secondly, wearable technology offers educators the ability to explain topics where learners could not feasibly gain real world and first-hand experience by using virtual reality or augmented reality features. Thirdly, wearable technology can augment collaboration between students and educators. Fourthly, wearable technology also can foster students' creativity and imagination, help students to manage their learning suitable to their own pace and on their path. Ultimately, wearable technology can stimulate an engaging learning environment appropriate to the different type of students' learning styles [26]-[28].

Nevertheless, there is insufficient research on the use of wearable technology in education due to the limitation offered by wearable technology, resulting to little numbers of learning design, model, and framework proposed by researchers in implementing wearable technology in teaching and learning process [24]. Due to the limited information and resources in this area, it is difficult for educators in designing an engaging e-content and e-activities for technical MOOCs using wearable technology. Due to the above issue, the purpose of this study is to enhance the current technical MOOC model with the assistance of wearable technology. Below is the list of research problems that we tried to answer:

- RQ1: How to design an engaging e-content for technical MOOC?

- RQ2: How to design an engaging e-activity for technical MOOC that can equip the students with the capabilities intended for laboratory practices?

- RQ3: What is the students' perception of the proposed technical MOOC?

\section{A. Technical Education and MOOCs}

Technical education or engineering education is the teaching and learning process that is associated with the practice of the engineering profession. Theoretical and conceptual learning for each technical subject is fundamental however, the practice-based learning is the critical element in the engineering profession [13], [29]. Thus, the laboratory exercises are a distinctive element that builds up the technical education. Moreover, in technical courses, the attendance of students in laboratories is necessary, and the theory must be practiced and conveyed through hands-on training [30]. In reflection with the online learning, where in this case we are referring to the development of technical MOOCs, few researchers suggested that the inclusion of the elements of virtual laboratories, remote laboratories, inperson laboratories or simulators can be considered as one of the options in implementing the theory-to-practice element in online courses [5], [13], [29]-[31].

A study conducted by Loro, et al. [5] introduced the use of a remote laboratory in the MOOC platform. The authors explained that the remote laboratories are designed with a pedagogical purpose that holds an advantage compared to inperson laboratories, and most importantly is highly available for the users [5]. The study also integrated the use of a remote lab with UNED-COMA platform into MOOCs and measured the students' dropout rate at the end of the course. The results of the study revealed that the use of the UNEDCOME platform is not suitable to be integrated with remote laboratories in MOOC platform. This causes the students to have less access to the learning materials, which resulted in a high dropout rate [5].

Another study conducted by Garcia, et al. [13] explained that they included a remote laboratory element called Virtual Instrument System in Reality or VISIR in their MOOC course and most of the MOOC videos focusing on handling the remote laboratory instruments. However, the authors highlighted that there is a limitation when working with the remote laboratory as it is not the same when dealing with the real circuit implementation where the lecturer's existence element showing the real circuit demonstration is necessary [5], [13], [31].

Therefore, the integration of either virtual laboratories, remote laboratories, in-person laboratories or simulators with MOOCs platform together with an engaging theory-topractice and practice-based learning design can improve the drawbacks held by either in-person laboratories, remote laboratories, virtual laboratories or simulators.

\section{B. Wearable Technology in Education}

Current researchers have offered some interesting findings of using wearable technology in all fields with 
different implementation background. However, the use of wearable technology can be mostly seen in these two main areas, which are in medical and education. Few studies in medical [27], [32], [33] suggested the inclusion of the use of wearable technology in order to engage the medical students. Wearable technology is a technology that the user can wear on their body. The recording ability possessed by wearable technology is able to capture a first-person view and realtime video especially for training purpose [27], [32]-[35].

Another study investigating the use of wearable technology in promoting hands-free learning cited that wearable technology allows educator and student to have better collaboration between each other by using hands-free devices, and most of the applications are in the fields of medicine and higher education [6]. In addition, Bower and Sturman [26] highlighted 13 functionalities of wearable technology in education context which are the ability of in situ contextual information, recording ability, simulation, communication, first-person view, engagement, in situ guidance, hands-free access, fast feedback, efficiency, presence, distribution, and gamification capabilities [26]. However as mentioned earlier, there are insufficient research on the use of wearable technology in education due to the limitation offered by wearable technology [24], resulting in the little numbers of learning design, model, and framework proposed by researchers to implement wearable technology in teaching and learning process. Therefore, in the next section, we will discuss the current practice of the MOOC design by combining the functionalities offered by the wearable technology that build-up an engaging technical MOOCs.

\section{Identified Technical MOOCs Design Elements}

A systematic review method was implemented to collect and critically analyze all required information and supporting materials for this study. We accomplished this in 3 phases. The first phase involved the search and selection of current practice of the MOOC design. In the second phase, the categorization of the most suitable and best practice was decided, and in the third phase, best practices were selected. Below is the summary of the current practice of the MOOC design categorized as e-content and e-activity, by combining the functionalities offered by the wearable technology to create engaging technical MOOCs. Table 1 and Table 2 summarize the literature findings of MOOC e-content and eactivity elements divided into basic MOOC design elements and technical MOOC design elements.

\section{Review of Technical MOOCs Model}

Classification of MOOC is differed depending on the pedagogical design, course learning design, course learning outcomes, and the learners' proficiency. The common literature on MOOC is classified into two kinds of MOOCs, which are xMOOC and cMOOC [36]. Most of the current MOOCs development is focusing on content-based MOOCs or xMOOCs. This type of MOOC focuses on the development of the course using different knowledge of content learning design and different assessment methods to assess the learner's mastery of the knowledge [44]. XMOOCs content design generally focuses on producing pre-recorded short lecture videos, supported with supplementary readings documents, and more on self-test problems activities in the form of multiple-choice or shortanswer quizzes, which are auto-graded, and peer-graded assignments on weakly basis.

Another kind of MOOCs is known as cMOOCs or connectivist MOOCs. CMOOCs are based on the learning theory of Connectivism which emphasizes the influence of connecting with other people. Learners in a cMOOC will create and generate their knowledge through co-creation assignments with peers. They will interact and collaborate with each other in completing the course activities assigned to them [45]. The learning process occurs within the network, where learners make a connection with the learning content, learning communities and other learners to create and construct the knowledge. The role of the instructor is to act as a facilitator by aggregating, reviewing, summarizing and reflecting participant's activity on a daily or weekly basis [12].

TABLE I

MOOC E-CONTENT DESIGN ELEMENTS

\begin{tabular}{|c|c|c|c|c|c|c|c|c|c|c|c|c|c|c|c|}
\hline & $\begin{array}{l}\text { e-Content } \\
\text { element }\end{array}$ & [2] & [5] & [7] & [13] & [31] & {$[32]$} & [36] & [37] & [38] & [39] & [40] & [41] & [42] & [43] \\
\hline \multirow{6}{*}{ 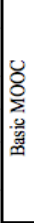 } & Lecture video & $\mathrm{x}$ & $\mathrm{x}$ & $\mathrm{x}$ & $\mathrm{x}$ & $\mathrm{x}$ & $\mathrm{x}$ & $\mathrm{x}$ & $\mathrm{x}$ & $\mathrm{x}$ & $\mathrm{x}$ & $\mathrm{x}$ & $\mathrm{x}$ & $\mathrm{x}$ & $\mathrm{x}$ \\
\hline & $\begin{array}{l}\text { Animated } \\
\text { lecture video }\end{array}$ & $\mathrm{x}$ & & $\mathrm{x}$ & & & & & $\mathrm{x}$ & $\mathrm{x}$ & & & & & \\
\hline & Audio files & $\mathrm{x}$ & & & & & $\mathrm{X}$ & & & $\mathrm{x}$ & & & & & \\
\hline & Documents & $\mathrm{x}$ & $\mathrm{x}$ & $\mathrm{x}$ & $\mathrm{x}$ & $\mathrm{x}$ & $\mathrm{x}$ & $\mathrm{x}$ & $\mathrm{x}$ & $\mathrm{x}$ & $\mathrm{x}$ & $\mathrm{x}$ & $\mathrm{x}$ & $\mathrm{x}$ & $\mathrm{x}$ \\
\hline & $\begin{array}{l}\begin{array}{l}\text { Presentation } \\
\text { files }\end{array} \\
\end{array}$ & $\mathrm{x}$ & $\mathrm{x}$ & $\mathrm{x}$ & $\mathrm{x}$ & $\mathrm{x}$ & $\mathrm{x}$ & $\mathrm{x}$ & $\mathrm{x}$ & $\mathrm{x}$ & $\mathrm{x}$ & $\mathrm{x}$ & $\mathrm{x}$ & $\mathrm{X}$ & $\mathrm{x}$ \\
\hline & Hypertext & $\mathrm{x}$ & & $\mathrm{x}$ & & & & & $\mathrm{x}$ & & $\mathrm{x}$ & $\mathrm{x}$ & & & $\mathrm{x}$ \\
\hline \multirow{6}{*}{ 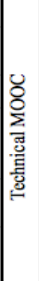 } & Tutorial video & $\mathrm{x}$ & $\mathrm{x}$ & & $\mathrm{x}$ & $\mathrm{x}$ & $\mathrm{x}$ & $\mathrm{x}$ & & & $\mathrm{x}$ & $\mathrm{x}$ & & & \\
\hline & \begin{tabular}{|l} 
Real demo \\
example
\end{tabular} & $\mathrm{x}$ & $\mathrm{x}$ & $\mathrm{x}$ & $\mathrm{x}$ & $\mathrm{x}$ & $\mathrm{X}$ & & $\mathrm{x}$ & $\mathrm{x}$ & & $\mathrm{x}$ & $\mathrm{x}$ & $\mathrm{x}$ & $\mathrm{x}$ \\
\hline & Field trip video & & & & & & & & & $\mathrm{x}$ & & & & & \\
\hline & \begin{tabular}{|l} 
Industrial \\
application \\
video
\end{tabular} & & & $\mathrm{x}$ & & & & & $\mathrm{x}$ & $\mathrm{x}$ & & & $\mathrm{x}$ & $\mathrm{x}$ & $\mathrm{x}$ \\
\hline & $\begin{array}{l}\text { Simulation } \\
\text { video }\end{array}$ & & & & $\mathrm{x}$ & & $\mathrm{x}$ & & & $\mathrm{x}$ & & & $\mathrm{x}$ & & \\
\hline & $\mid \begin{array}{l}\text { VR-based } \\
\text { content delivery }\end{array}$ & & & $\mathrm{x}$ & & & $\mathrm{x}$ & & & $\mathrm{x}$ & & & $\mathrm{x}$ & & \\
\hline
\end{tabular}

TABLE II

MOOC E-ACTIVITY DESIGN ELEMENTS

\begin{tabular}{|c|c|c|c|c|c|c|c|c|c|c|c|c|c|c|c|}
\hline & \begin{tabular}{|l} 
e-Activity \\
element
\end{tabular} & [2] & [5] & [7] & [13] & {$[31]$} & [32] & [36] & [37] & [38] & [39] & [40] & {$[41]$} & {$[42]$} & [43] \\
\hline \multirow{7}{*}{ 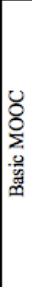 } & Quizzes & $\mathrm{x}$ & $\mathrm{x}$ & $\mathrm{x}$ & $\mathrm{x}$ & $\mathrm{x}$ & $\mathrm{x}$ & $\mathrm{x}$ & $\mathrm{x}$ & $\mathrm{x}$ & $\mathrm{x}$ & $\mathrm{x}$ & $\mathrm{x}$ & $\mathrm{x}$ & $\mathrm{X}$ \\
\hline & $\begin{array}{l}\begin{array}{l}\text { Game-based } \\
\text { activity }\end{array} \\
\end{array}$ & $\mathrm{x}$ & & & & & & $\mathrm{x}$ & & & & & & & \\
\hline & Forum & $\mathrm{x}$ & & $\mathrm{x}$ & $\mathrm{x}$ & $\mathrm{x}$ & $\mathrm{x}$ & & $\mathrm{x}$ & $\mathrm{x}$ & $\mathrm{x}$ & & $\mathrm{x}$ & $\mathrm{x}$ & $\mathrm{x}$ \\
\hline & Assignment & $\mathrm{x}$ & $\mathrm{X}$ & $\mathrm{x}$ & $\mathrm{x}$ & $\mathrm{x}$ & & $\mathrm{x}$ & $\mathrm{x}$ & $\mathrm{X}$ & $\mathrm{X}$ & $\mathrm{x}$ & & $\mathrm{x}$ & \\
\hline & \begin{tabular}{|l|} 
Wiki \\
\end{tabular} & $\mathrm{x}$ & & & & $\mathrm{x}$ & & & & & $\mathrm{x}$ & & & & $\mathrm{x}$ \\
\hline & Social network & $\mathrm{x}$ & & & & & & & & $\mathrm{x}$ & & & $\mathrm{x}$ & & \\
\hline & Peer assessment & $\mathrm{x}$ & $\mathrm{x}$ & & & $\mathrm{x}$ & $\mathrm{x}$ & $\mathrm{x}$ & $\mathrm{x}$ & $\mathrm{x}$ & $\mathrm{x}$ & & & $\mathrm{x}$ & $\mathrm{x}$ \\
\hline \multirow{8}{*}{ 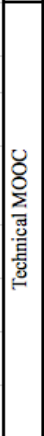 } & \begin{tabular}{|l|} 
In-person \\
laboratories
\end{tabular} & & $\mathrm{x}$ & & & $\mathrm{X}$ & & & & & & $\mathrm{x}$ & & & \\
\hline & Simulation & & $\mathrm{X}$ & & & & & & & & & $\mathrm{x}$ & $\mathrm{x}$ & & \\
\hline & $\begin{array}{l}\begin{array}{l}\text { Project-based } \\
\text { activity }\end{array} \\
\end{array}$ & $\mathrm{x}$ & $\mathrm{x}$ & & & $\mathrm{x}$ & & & $\mathrm{x}$ & $\mathrm{X}$ & & $\mathrm{X}$ & & & \\
\hline & \begin{tabular}{|l} 
Video \\
uploading \\
(demo skills)
\end{tabular} & & & & & & $\mathrm{x}$ & $\mathrm{x}$ & & & & & & & $\mathrm{X}$ \\
\hline & \begin{tabular}{|l|} 
Live-video \\
conference
\end{tabular} & & & & & & $x$ & & & & & & $\mathrm{x}$ & $\mathrm{X}$ & $\mathrm{X}$ \\
\hline & \begin{tabular}{|l|} 
AR-based \\
design activity \\
\end{tabular} & & & & & & $\mathrm{x}$ & & & & & & $\mathrm{x}$ & & $\mathrm{x}$ \\
\hline & \begin{tabular}{|l} 
Remote \\
laboratories
\end{tabular} & & $x$ & & $\mathrm{X}$ & & & & & & & & & & \\
\hline & \begin{tabular}{|l} 
Virtual \\
laboratories
\end{tabular} & & $\mathrm{x}$ & & & & & & & & & $\mathrm{X}$ & & & \\
\hline
\end{tabular}


Some MOOCs are suitable in between xMOOC and cMOOC called pMOOC (or project-based MOOC). PMOOCs focus on the content-based and are a highly structured MOOC regarding how the course content is organized and presented but also blend in a project-based model of assessment into its learning design [36]. In this type of MOOC, the task for the learners is to design a project to be reviewed by peers using an articulated rubric, created by the instructor [36]. Course completion requirements in a pMOOC typically include submitting projects for peer grades and reviews of some mini-projects designed by peers [36]. In this study, we adopted the final model of MOOCs as per proposed by Hew [2] which consists of six main MOOC elements which are course information (CI), course resources (CR), interaction (IN), meaningful connections (MC), monitoring learning (ML), and active learning (AL). Table 3 summarizes the identified MOOC elements based on the combination of $\mathrm{xMOOC}$, cMOOC, and pMOOC, based on a systematic literature review from the year 2014 until 2017. Table 4 lists the explanation for each of the identified MOOC elements together with its suitable MOOC e-contents and e-activities as per suggested by [2].
TABLE III

REVIEW OF MOOC ELEMENTS

\begin{tabular}{|c|c|c|c|c|c|c|}
\hline \multirow{2}{*}{$\begin{array}{c}\text { Previous } \\
\text { works }\end{array}$} & \multicolumn{7}{|c|}{ MOOC elements } \\
\hline & CI & CR & IN & MC & ML & AL \\
\hline$[1]$ & $\mathrm{X}$ & $\mathrm{X}$ & $\mathrm{X}$ & $\mathrm{X}$ & $\mathrm{X}$ & $\mathrm{X}$ \\
\hline$[2]$ & $\mathrm{X}$ & $\mathrm{X}$ & $\mathrm{X}$ & $\mathrm{X}$ & $\mathrm{X}$ & $\mathrm{X}$ \\
\hline$[6]$ & $\mathrm{X}$ & $\mathrm{X}$ & $\mathrm{X}$ & & $\mathrm{X}$ & \\
\hline$[10]$ & & $\mathrm{X}$ & $\mathrm{X}$ & & $\mathrm{X}$ & $\mathrm{X}$ \\
\hline$[11]$ & $\mathrm{X}$ & $\mathrm{X}$ & $\mathrm{X}$ & $\mathrm{X}$ & $\mathrm{X}$ & $\mathrm{X}$ \\
\hline$[12]$ & $\mathrm{X}$ & $\mathrm{X}$ & $\mathrm{X}$ & & $\mathrm{X}$ & $\mathrm{X}$ \\
\hline$[13]$ & $\mathrm{X}$ & $\mathrm{X}$ & $\mathrm{X}$ & $\mathrm{X}$ & $\mathrm{X}$ & $\mathrm{X}$ \\
\hline$[17]$ & & & $\mathrm{X}$ & $\mathrm{X}$ & $\mathrm{X}$ & $\mathrm{X}$ \\
\hline$[36]$ & & $\mathrm{X}$ & $\mathrm{X}$ & & & $\mathrm{X}$ \\
\hline$[38]$ & $\mathrm{X}$ & $\mathrm{X}$ & $\mathrm{X}$ & $\mathrm{X}$ & $\mathrm{X}$ & $\mathrm{X}$ \\
\hline$[46]$ & $\mathrm{X}$ & $\mathrm{X}$ & $\mathrm{X}$ & $\mathrm{X}$ & $\mathrm{X}$ & $\mathrm{X}$ \\
\hline$[47]$ & $\mathrm{X}$ & $\mathrm{X}$ & $\mathrm{X}$ & $\mathrm{X}$ & $\mathrm{X}$ & $\mathrm{X}$ \\
\hline$[48]$ & $\mathrm{X}$ & $\mathrm{X}$ & $\mathrm{X}$ & $\mathrm{X}$ & $\mathrm{X}$ & $\mathrm{X}$ \\
\hline$[49]$ & $\mathrm{X}$ & $\mathrm{X}$ & $\mathrm{X}$ & & $\mathrm{X}$ & $\mathrm{X}$ \\
\hline$[50]$ & $\mathrm{X}$ & $\mathrm{X}$ & $\mathrm{X}$ & $\mathrm{X}$ & & $\mathrm{X}$ \\
\hline$[51]$ & $\mathrm{X}$ & $\mathrm{X}$ & & $\mathrm{X}$ & & $\mathrm{X}$ \\
\hline$[52]$ & $\mathrm{X}$ & $\mathrm{X}$ & $\mathrm{X}$ & & $\mathrm{X}$ & $\mathrm{X}$ \\
\hline$[53]$ & $\mathrm{X}$ & $\mathrm{X}$ & $\mathrm{X}$ & & $\mathrm{X}$ & $\mathrm{X}$ \\
\hline$[54]$ & $\mathrm{X}$ & $\mathrm{X}$ & $\mathrm{X}$ & & $\mathrm{X}$ & $\mathrm{X}$ \\
\hline$[55]$ & & $\mathrm{X}$ & $\mathrm{X}$ & & $\mathrm{X}$ & $\mathrm{X}$ \\
\hline
\end{tabular}

TABLE IV

EXPLANATION OF EACH TECHNICAL MOOC ELEMENTS

\begin{tabular}{|c|c|c|}
\hline MOOC element & Description & MOOC e-content/ e-activity elements \\
\hline $\begin{array}{l}\text { Course } \\
\text { information }\end{array}$ & $\begin{array}{l}\text { Course content must include a clear } \\
\text { statement of what the learner can hope } \\
\text { to achieve upon successful } \\
\text { completion }^{1(\text { a) }}\end{array}$ & $\begin{array}{l}\text { a. Explain the course objective } \\
\text { b. Share the course duration } \\
\text { c. State the estimated workload } \\
\text { d. Share the language to be used throughout the course } \\
\text { e. Explain the course syllabus } \\
\text { f. Share any recommended pre-requisite requirements to enroll in the course }\end{array}$ \\
\hline Course resource & $\begin{array}{l}\text { Course resources/ materials must } \\
\text { contain facts, updated information, } \\
\text { concepts or approaches. Course } \\
\text { materials are structured to facilitate } \\
\text { individual study }^{1(b)}\end{array}$ & $\begin{array}{l}\text { a. Using short videos (mostly about 5-6 minutes long) } \\
\text { b. Provide slides or notes to accompany video lectures } \\
\text { c. Information is explained in simple-to-understand language } \\
\text { d. Supporting documents is relevant, interesting, accurate, and current information } \\
\text { e. Include captions on videos } \\
\text { f. Downloadable and sharable videos } \\
\text { g. Provide students the ability to vary the speed of the videos }\end{array}$ \\
\hline Interaction & $\begin{array}{l}\text { Course design and delivery can } \\
\text { support student-student and student- } \\
\text { lecturer interaction. Use a different } \\
\text { kind of collaboration tools such as } \\
\text { social media, email, forum and chat } \\
\text { 1(a)(c)(d) }\end{array}$ & $\begin{array}{l}\text { Student-student interaction } \\
\text { a. Use of an asynchronous discussion forum for students to interact } \\
\text { Student-lecturer interaction } \\
\text { a. Responsive to students' inquiries } \\
\text { b. The use of a dedicated course email to seek instructor's help }\end{array}$ \\
\hline $\begin{array}{l}\text { Meaningful } \\
\text { connection }\end{array}$ & $\begin{array}{l}\text { Course content and activity that can } \\
\text { connect the learners to the actual } \\
\text { practice in the larger world which } \\
\text { they could identify }\end{array}$ & $\begin{array}{l}\text { a. Real illustrative examples } \\
\text { b. Real case study } \\
\text { c. Activities that require students to create and participate that make a direct connection } \\
\text { with the key concepts of the course with a real scenario }\end{array}$ \\
\hline $\begin{array}{l}\text { Monitoring of } \\
\text { learning }\end{array}$ & $\begin{array}{l}\text { Always monitor learners' progress by } \\
\text { providing helpful and prompt } \\
\text { comments of their progress about the } \\
\text { learning outcome }\end{array}$ & $\begin{array}{l}\text { a. Use auto-graded activities and quizzes based on a weekly basis. Each activity contains a } \\
\text { problem to be solved by students }\end{array}$ \\
\hline Active learning & $\begin{array}{l}\text { Course activities that involved } \\
\text { learners in doing things and thinking } \\
\text { about the things they are doing }\end{array}$ & $\begin{array}{l}\text { a. Use of active learning strategies so that students could apply some of the principles } \\
\text { related to the course } \\
\text { b. Use of self-assessment activity as part of students required the assignment }\end{array}$ \\
\hline
\end{tabular}




\section{MATERIAL AND METHOD}

Based on the previous critical literature review as presented earlier, Fig.1 illustrates the proposed model of technical MOOC used in this study, while Fig. 2 illustrates the details of the elements that build-up the proposed technical MOOC model using wearable technology which is divided into e-content and e-activity known as mechanical MOOC learning design structure. The elements or learning materials based on wearable technology production was highlighted in orange color. There are several learning material resources, which have been classified as the econtent in the development of this technical MOOC. The econtent included in the MOOC development are lecture videos, lab demo videos, live-video conference, tutorial solution videos, field trip video, live-video conferencing, lecture slides, and extra reading materials. While the eactivity included in the MOOC development are online lab submission, online interactive activities, self-lab video upload, discussion, remote laboratory, and tutorial exercises. The design of these learning activities is to support the practice-based learning outcome, and at the same time to engage the students' learning with the technical MOOC.

To test the effectiveness of the proposed model, a technical MOOC course was designed and developed. A quantitative based approach was chosen as the method for this study. An online questionnaire type was used as the main data collection method. This section explains the sample was chosen, data collection procedures, survey instruments, and details of the technical MOOC.

\section{A. Participants and Data Collection}

The evaluated title of the MOOC course is Principle of Electrical and Electronic MOOC. We conducted a case study research method to assess engineering students' perceptions based on the technical MOOC course offered to them. A case study method is one of the research methods that can be used when we want to narrow down from a vast research field into a particular and easily researchable scope. Moreover, the case study method is also suitable for testing theoretical models by applying it in the real situation. Also, an online questionnaire was used to collect quantitative data for the study. There was 43 engineering students participated in this study, who are currently in their second year of study. 72 percent (30 students) of the participants are male while the remaining 28 percent (13 students) are female.

The data collection involved three significant phases. Firstly, the respondents were asked to experience the used of Open Learning platform (which is MOOC) by the respective lecturers during the lecture hours. Secondly, they were asked to enroll into required technical MOOC course and participate in it for three weeks: watching videos, answering online quizzes, posting responses to forums, uploading videos, and other activities included in the technical MOOC. Thirdly, the respondents were asked to evaluate the technical MOOC course effectiveness critically based on specific criteria set using the online questionnaire platform. All the collected data were used to further analyze the students' perception on the technical MOOC.

\section{B. Instrument}

The questionnaire was designed based on a model of engaging online students organized around selfdetermination theory (SDT) and MOOC elements as per suggested by Hew [2]. The main structure for the technical MOOC model was a combination of four different online learning policy documents prepared by professional online learning councils from all over the world [2]. The respective four councils are: 1) Benchmark for Technology Supported Teaching and Learning from Australia; 2) Interregional Guidelines for the Evaluation of Distance Education Programs (Online Learning) from the USA; 3) Open and Distance Learning Quality Council Standards from the UK; 4) Guidelines for the Implementation of Effective E-learning Courses [2].

For this study, the element of Student's Perception (SP) was then added to the model where the variable was to analyze the student's perception of technical MOOC course using wearable technology. There was 38 items with seven survey constructs. Fig. 3 illustrates an overview of instruments used to measure student's perception on technical MOOC.

\section{Details of Technical MOOC}

The name of the technical MOOC is "Principle of Electrical and Electronic" or PEE MOOC. As the starting stage, the implementation of this MOOC is currently still not in the fully online mode as it is being blended with the current face-to-face teaching and learning system.

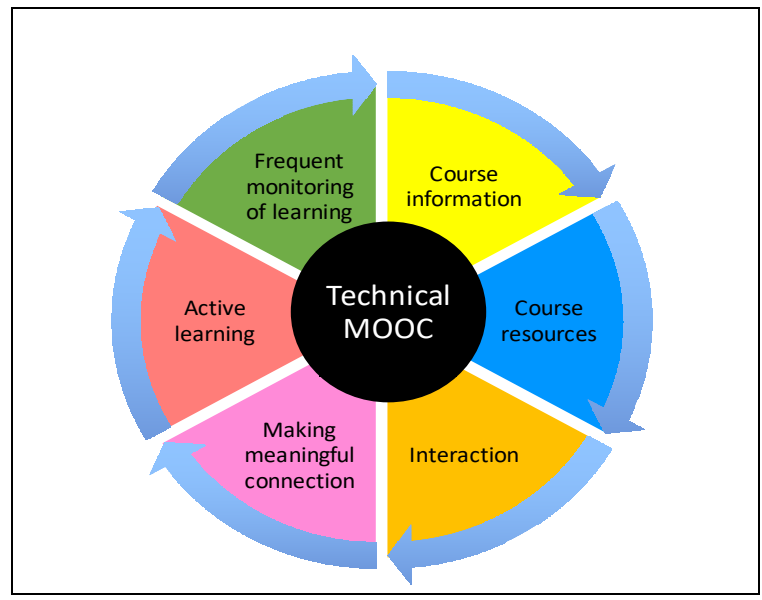

Fig. 1 A model of technical MOOC

The general learning goals as established in the syllabus, in the initial PEE MOOC web page, are:

- To identify common electrical and electronic components used in the schematic diagram according to standard symbols,

- To gain practical competencies in basic electrical and electronic circuits,

- To gain practical competencies in lab equipment used in electronics laboratories,

- To design simple electrical and electronics circuits according to design specifications,

- To demonstrate good practice safety standard, teamwork spirit, and communication skills adequately. 


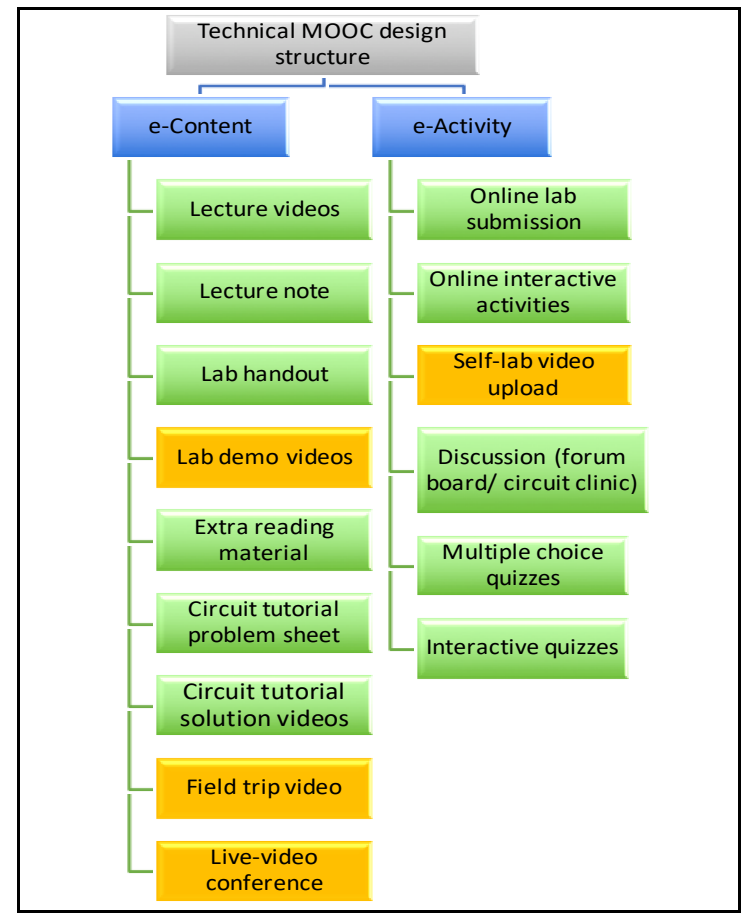

Fig. 2 Technical MOOC learning design structure (elements for e-content and e-activity)

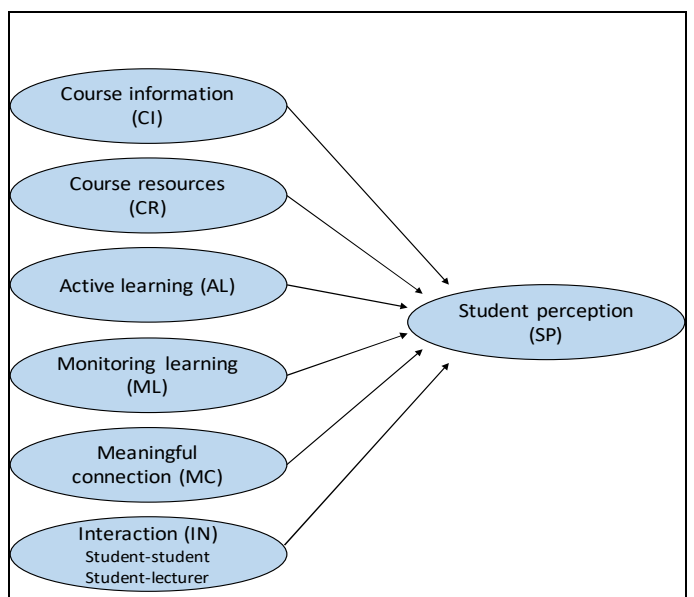

Fig. 3 An overview of instruments used to measure student's perception on technical MOOC

Based on the critical review and all the advantages offered by wearable technology, thus wearable technology, wherein this study is the Google Glass, is used in developing the PEE MOOC course. In this study, Google Glass is used as one of the main recording devices in recording all videos. All videos recorded using the Google Glass were captured from the lecturer's point-of-view. This is the most important feature possessed by the Google Glass in order to engage the students more with the learning process. A study conducted by [55] proved that students engage more with the lecture and tutorial videos when the video production focuses more on the first watch experience and has ability to add support for re-watching and skimming. Thus, by using the Google Glass as the video production tool, this allows the students to view from the lecturer's perspective and increase their understanding. Students can watch lab tutorial videos captured from the lecturer's point-of-view. This can help the students to do things right at the first time. All videos, documents, and activities were designed and prepared in English. In total, the PEE MOOC course contains:

- 14 videos (including lecture videos, lab tutorials videos, and circuit exercise solution videos, field trip video, industrial application video, Real Case Study video and live video conference on lab demo)

- 20 activities (including multiple choice questions, group discussion activities, colour code practice, dragand-drop activities, and lab submission activities)

- 13 documents (including lecture notes, lab handouts, and other supporting materials)

Fig. 4 shows a picture of lecturer using the Google Glass to do the recording of lab demo activity. Fig. 5 shows a screenshot of a video from one of the lab tutorial modules captured using the Google Glass, which was uploaded in the MOOC platform. While Fig. 6 shows a screenshot of the overall MOOC modules and activities.

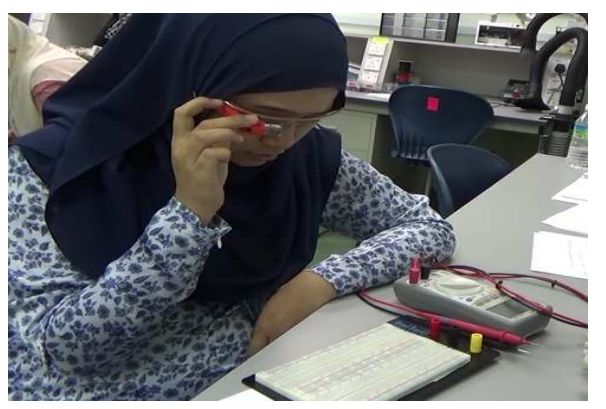

Fig. 4. Lecturer using Google Glass to do the recording of lab demo activity

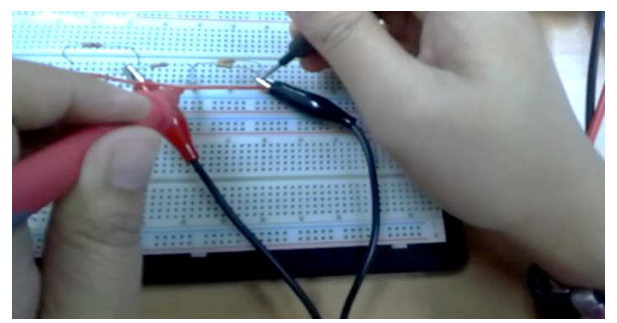

Fig. 5. Screenshot of a video from one of the lab tutorial videos module that captured using wearable technology

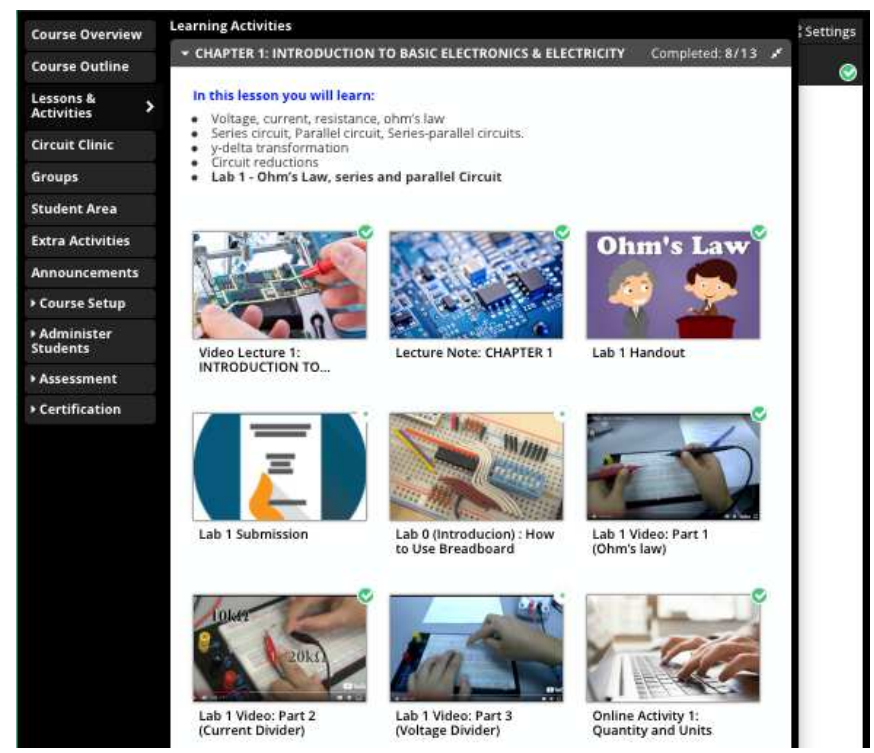

Fig. 6 Structure of technical MOOC modules and activities 


\section{RESULTS AND DISCUSSION}

This section discusses all the results and findings gathered from the data analysis. The data were analyzed using SPSS. In this study, the analyses of the data were based on reliability test results and correlation analysis results.

\section{A. Reliability Test}

To ensure the reliability of the constructs used to measure the students' perception of PEE MOOC used in this study, a reliability test was conducted. The Cronbach's Alpha value reflected that all the variables were acceptable (values above .70). Table 5 presents the Cronbach Alpha value for each of the construct and a total number of items per each construct.

TABLE V

CRONBACH's AlPHA RESUlts

\begin{tabular}{|l|c|c|}
\hline Components & Cronbach's Alpha & Items \\
\hline Course information & .945 & 5 \\
\hline Course resources & .957 & 9 \\
\hline Active learning & .986 & 4 \\
\hline Monitoring learning & .968 & 3 \\
\hline Meaningful connection & .950 & 7 \\
\hline Interaction & .823 & 7 \\
\hline Intended perception & .935 & 3 \\
\hline
\end{tabular}

\section{B. Correlation Analysis}

In the third research question, we try to identify the students' perception on the technical MOOC, either the students possess positive or negative perception when learning through MOOC. To answer this, we used a relationship analysis approach to analyze the data. Several statistical analyses can be used in exploring the relationship between variables such as correlation analysis, regression analysis, and factor analysis. However, the one that best suits this study is correlation analysis. Correlation analysis is used to explain the strength and the direction of the linear relationship between two variables [56]. Therefore, in this study, we tried to identify the positive or negative relationship between six variables of technical MOOC with the students' perception.

The correlation analysis revealed that $\mathrm{CI}, \mathrm{CR}, \mathrm{AL}, \mathrm{ML}$, MC and IN positively correlated with the SP. The CI, CR, $\mathrm{AL}, \mathrm{MC}$ and IN variables were above the preferable cut-off point of .3 with $.827, .974, .516, .475, .412$ respectively [57]. This reflects that the majority of the technical MOOC variables correlated substantially with students' perception variable, $r=.3$ to $1.0, \mathrm{n}=43, p<.0005$. Besides, there was a large correlation between CI, CR and AL variables (where $r$ value above .50) [57] with students' perception. This also reflects the strong (positive) relationship between CI, CR and AL with students' perception $(.827, .974$ and .516 respectively). MC and IN held .475 and .412 respectively of the size value of the correlation coefficient which reflected a medium correlation ( $r$ value between .30 and .49 ) and drew a moderate (positive) relationship with intended perception [57]. On the other hand, ML held a small coefficient ( $r$ value .10 to .20) [57] or weak (positive) relationship with intended perception with value .218 . This reflects that all six instruments of technical MOOC elements built using wearable technology draw a positive direction of the relationship with students' perception.

From correlation analysis, it can be concluded that adequate course information does influence the positive perception of students on the technical MOOC course. Besides, engaging technical MOOC course resources (consist of the e-content and e-activity) also bring a positive perception of students. The active learning strategies included in the technical MOOC course also do influence the positive perception of students through the learning process. Moreover, effective monitoring of learning over the technical MOOC course and implementation of meaningful connection does bring the positive perception of students. The interactions among students and student, and student with educators also do affect the positive perception of students' learning on the technical MOOC course.

In addition, this result also suggests that the learning materials produced by wearable technology which consist the elements of lab demo videos, field-trip video, live-video conference and uploading self-lab video do contribute towards the positive effect of students' perception when learning technical MOOC. Consequently, the overall conclusion from the correlation test is that all technical MOOC variables hold a positive relationship with students' perception variable, which does affect the positive perception of students on the technical MOOC learning.

Table 6 presents an overview of means, standard deviation, and inter-correlations for students' perception and six elements of technical MOOC.

TABLE VI

MEANS, STANDARD DEVIATION, AND INTER-CORRELATIONS FOR PERCEPTION AND INDEPENDENT VARIABLES

\begin{tabular}{|c|c|c|c|c|c|c|c|c||}
\hline Variable & $M$ & $S D$ & CI & CR & AL & ML & MC & IN \\
\hline SP & 13.94 & 1.35 & $.827 * *$ & $.974^{* *}$ & $.516^{* *}$ & .218 & $.475^{* *}$ & $.412^{*}$ \\
\hline CI & 22.06 & 3.22 & - & $.877^{* *}$ & $.460^{* *}$ & $.466^{* *}$ & $.479^{* *}$ & $.495^{* *}$ \\
\hline CR & 41.97 & 3.67 & & - & $.543^{* *}$ & .218 & $.518^{* *}$ & $.437 * *$ \\
\hline AL & 17.00 & 2.54 & & & - & .248 & .080 & .100 \\
\hline ML & 13.83 & 1.81 & & & & - & $.492^{* *}$ & $.520^{* *}$ \\
\hline MC & 32.89 & 2.80 & & & & & - & $.745^{* *}$ \\
\hline IN & 30.97 & 3.03 & & & & & & - \\
\hline ** p<.001 (2-tailed). & & & & \\
\hline
\end{tabular}

\section{CONCLUSION}

This paper presents the current practice of the MOOC design (e-content and e-activity) by combining the functionalities offered by the wearable technology that build-up an engaging technical MOOCs. We also conducted a survey in order to identify the students' perception on technical MOOC. Based on the findings, adequate course information about the MOOC course, engaging MOOC course resources, and active learning strategies included in the MOOC course were able to lead towards a positive perception of the students. In addition, effective monitoring of learning over the MOOC, meaningful connection implemented in MOOC, and two ways interactions (studentstudent, student-lecturer) in MOOC another important aspect were able to lead towards a positive perception of students in 
learning. The correlation analysis results revealed that all six variables had positive relationship with students' perception, which reflects that students possess a positive perception when learning through MOOC.

Understanding the relationship of students' perception of learning through MOOC is only the starting platform to further develop more effective and efficient teaching and learning planning guideline. By introducing MOOC as one of the options that can be used by the community to support lifelong learning, the process to acquire the knowledge and learning can be done continuously. This paper also: i) shares the urgency in identifying the students' perception towards supporting the student growth and achievement, ii) provides a reflection on the effectiveness of teaching and learning process and iii) also can promote further improvement towards the successful implementation of online learning initiatives.

For future works, the researchers will further conduct a triangulation process (interview session with students and lecturers) in order to confirm findings from this study. In addition, engagement analysis on each of the MOOC instructional design elements will be further analyzed to identify which elements that able to engage more with the students. This finding will provide another interesting view that can be further explored.

\section{ACKNOWLEDGMENT}

The authors would like to take this opportunity to highly appreciate the cooperation given by the lecturers who gave their full support in this research, the opportunity given by UTeM, and all the respective students for their help in obtaining the data for the research. Not forgotten, a special thanks to UTeM Zamalah Scheme for funding this research. Pervasive Computing and Educational Technology Research Group, C-ACT, Universiti Teknikal Malaysia Melaka conduct this research.

\section{REFERENCES}

[1] J. Mullen, C. Byun, V. Gadepally, S. Samsi, A. Reuther and J. Kepner, "Learning by doing, High-Performance Computing education in the MOOC era," Journal of Parallel and Distributed Computing, 2017.

[2] K. F. Hew, "Towards a model of engaging online students: lessons from MOOCs and four policy documents," International Journal of Information and Education Technology 5, no. 6, pp. 425-431, 2015.

[3] Y. P. L. Zhu and J. Shang, "Improving Video Engagement by Gamification: A Proposed Design of MOOC Videos," International Conference on Blended Learning, pp. 433-444, 2017.

[4] MoocLab, 2017. MoocLab Report: The Global MOOC Landscape 2017 A look at the numbers, the geography \& the language of MOOCs. [Online] Available at: https://www.mooclab.club/ resources/mooclab-report-the-global-MOOC-landscape-2017.214/

[5] F. G. Loro, A. Macho, E. Sancristobal, M. R. Artacho, G. Díaz and M. Castro, "Remote laboratories for electronics and new steps in learning process integration," Remote Engineering and Virtual Instrumentation (REV), 2016 13th International Conference, pp. 112117, 2016.

[6] N. Spyropoulou, C. Pierrakeas, and A. Kameas, "Creating MOOC Guidelines based on best practices," EDULEARN14 Proceedings, pp. 6981-6990, 2014

[7] L. Stuchlikova, A. Kosa, P. Benko and D. Donoval, "Massive open online courses in microelectronics education," Microelectronics Education (EWME), 10th European Workshop, pp. 31-36, 2014.

[8] T. Daradoumis, R. Bassi, F. Xhafa and S. Caballé, "A review on massive e-learning (MOOC) design, delivery and assessment," P2P,
Parallel, Grid, Cloud and Internet Computing (3PGCIC), 2013 Eighth International Conference, pp. 208-213, 2013.

[9] A. Bill, H. Maggie, N. Mark, C. Gráinne, S. Keith and V. Norm, "Alt-Ed: ASCILITE 2012," 2012. [Online]. Available: http://alternative-educate.blogspot.co.uk/2012/12/audio-ascilite2012-great-debate-moocs.html.

[10] K. S. Hone and G. R. El Said, "Exploring the factors affecting MOOC retention: A survey study," Computers \& Education, vol. 98, pp. 157-168, 2016.

[11] D. Gamage, I. Perera, and S. Fernando, "A framework to analyze the effectiveness of learning in MOOC: Learners perspective," 8th International Conference on Ubi-Media Computing (UMEDIA), pp. 236-241, 2015a.

[12] A. M. F. Yousef, M. A. Chatti, U. Schroeder and M. Wosnitza, "What drives a successful MOOC? An empirical examination of criteria to assure design quality of MOOCs," Advanced Learning Technologies (ICALT), 2014 IEEE 14th International Conference, pp. 44-48, 2014.

[13] F. Garcia, G. Diaz, M. Tawfik, S. Martin, E. Sancristobal and M. Castro, "A practice-based MOOC for learning electronics," Global Engineering Education Conference (EDUCON), pp. 969-974, 2014.

[14] A. Vaibhav and P. Gupta, "Gamification of MOOCs for increasing user engagement," MOOC, Innovation, and Technology in Education (MITE) 2014 IEEE International Conference, pp. 290-295, 2014.

[15] O. B. Gené, M. M. Núñez, and Á. F. Blanco, "Gamification in MOOC: challenges, opportunities, and proposals for advancing MOOC model," Proceedings of the Second International Conference on Technological Ecosystems for Enhancing Multiculturality, pp. 215-220, 2014.

[16] M. Furini, "On gamifying the transcription of digital video lectures," Entertainment Computing, 14, pp. 23-31, 2016.

[17] P. Ventura, E. Bárcena and E. Martín-Monje, "Analysis of the impact of social feedback on written production and student engagement in Language MOOCs," Procedia-Social and Behavioral Sciences, 141, pp. 512-517, 2014.

[18] N. Ostashewski, J. Howell, and J. Dron, "Crowdsourcing MOOC Interactions: Using a Social Media Site cMOOC to Engage Students in University Course Activities.," Pan-Commonwealth Forum 8, p. ID: 258, 2016.

[19] C. Gütl, R. H. Rizzardini, V. Chang and M. Morales, "Attrition in MOOC: Lessons learned from drop-out students," International Workshop on Learning Technology for Education in Cloud, pp. 3748, 2014.

[20] M. Ward, "Using animated visualization in Computer Assisted Language Learning," Human System Interactions (HSI), 2016 9th International Conference, pp. 38-44, 2016.

[21] N. Nordin, H. Norman, M. A. Embi, A. Z. Mansor and F. Idris, "Factors for Development of Learning Content and Task for MOOCs in an Asian Context," International Education Studies, 9(5), pp. 4861, 2016.

[22] S. F. A. Fesol and S. Salam, "Towards MOOC for technical courses: A blended learning empirical analysis," User Science and Engineering (i-USEr), 2016 4th International Conference, pp. 116$121,2016$.

[23] N. M. Hicks, D. Roy, S. Shah, K. A. Douglas, P. Bermel, H. A. Diefes-Dux and K. Madhavan, "Integrating analytics and surveys to understand fully engaged learners in a highly-technical STEM MOOC," Frontiers in Education Conference (FIE), 2016 IEEE, pp. 19, 2016.

[24] M. Bower and D. Sturman, "What are the educational affordances of wearable technologies?," Computers \& Education, 88, pp. 343-353, 2015.

[25] D. Sapargaliyev, "Wearable Technology in Education: From Handheld to Hands-Free Learning," Technology in Education. Transforming Educational Practices with Technology, pp. 55-60, 2015.

[26] I. Buchem, A. Merceron, J. Kreutel, M. Haesner and A. Steinert, "Designing for User Engagement in Wearable-technology Enhanced Learning for Healthy Ageing," Intelligent Environments (Workshops), pp. 314-324, 2015.

[27] B. Chaballout, M. Molloy, J. Vaughn, R. Brisson III and R. Shaw, "Feasibility of Augmented Reality in Clinical Simulations: Using Google Glass With Manikins," JMIR Medical Education, vol. 2, no. $1,2016$.

[28] S. Yuen, Y. Gallayanee and J. Erik, "Augmented reality: An overview and five directions for AR in education," Journal of 
Educational Technology Development and Exchange 4.1, pp. 119140, 2011.

[29] S. Iqbal, X. Zang, Y. Zhu, D. Hussain, J. Zhao, M. M. Gulzar and S. Rasheed, "Towards MOOCs and Their Role in Engineering Education," Information Technology in Medicine and Education (ITME), 2015 7th International Conference, pp. 705-709, 2015.

[30] M. Castro, M. Tawfik, F. García, F. Loro and E. Sancristobal, "Combining Remote Laboratories and Massive Open Online Courses (MOOCs) for Teaching Electronics," Society for Information Technology \& Teacher Education International Conference, pp. 2086-2090, 2014

[31] T. J. Zajdel and M. M. Maharbiz, "Introducing Electronics at Scale with a Massive Online Circuits Lab," Proceedings of the 123rd ASEE Annual Conference \& Exposition, 2016.

[32] T. Wu, C. Dameff, and J. Tully, "Integrating Google Glass into simulation-based training: experiences and future directions," Journal of Biomedical Graphics and Computing, 4(2), 49, 2014.

[33] D. A. Zahl, S. M. Schrader and P. C. Edwards, "Student perspectives on using egocentric video recorded by smart glasses to assess communicative and clinical skills with standardized patients," European Journal of Dental Education, 2016.

[34] S. Vallurupalli, H. Paydak, S. Agarwal, M. Agrawal and C. AssadKottner, "Wearable technology to improve education and patient outcomes in a cardiology fellowship program- A feasibility study," Health and Technology, vol. 3, no. 4, p. 267-270, 2013.

[35] W. Glauser, "Doctors among early adopters of Google Glass," Canadian Medical Association Journal 109, 2013.

[36] T. Phan, S. G. McNeil, and B. R. Robin, "Students' patterns of engagement and course performance in a Massive Open Online Course," Computers \& Education, 95, pp. 36-44, 2016.

[37] B. J. Swinnerton, N. P. Morris, S. Hotchkiss and J. D. Pickering, "The integration of an anatomy massive open online course (MOOC) into a medical anatomy curriculum," Anatomical sciences education, 10(1), pp. 53-67, 2017.

[38] W. Abeer and B. Miri, "Students' Preferences and Views about Learning in a MOOC," Procedia-Social and Behavioural Sciences, 152 , pp. 318-323, 2014

[39] M. Liu, J. Kang, M. Cao, M. Lim, Y. Ko, R. Myers and A. Schmitz Weiss, "Understanding MOOCs as an emerging online learning tool: Perspectives from the students," American Journal of Distance Education, 28(3), pp. 147-159, 2015.

[40] P. F. Mitros, K. K. Afridi, G. J. Sussman, C. J. Terman, J. K. White, L. Fischer and A. Agarwal, "Teaching electronic circuits online: Lessons from MITx's $6.002 \mathrm{x}$ on edX," Circuits and Systems (ISCAS), 2013 IEEE International Symposium, pp. 2763-2766, 2013.

[41] U. Rehman and S. Cao, "Augmented Reality-Based Indoor Navigation Using Google Glass as a Wearable Head-Mounted Display," Systems, Man, and Cybernetics (SMC), 2015 IEEE International Conference, pp. 1452-1457, 2015.

[42] X. S. Zheng, C. Foucault, P. Matos da Silva, S. Dasari, T. Yang and S. Goose, "Eye-wearable technology for machine maintenance: Effects of the display position and hands-free operation," Proceedings of the 33rd Annual ACM Conference on Human Factors in Computing Systems, pp. 2125-2134, 2015.
[43] J. Y. C. Chang, L. Y. Tsui, K. S. K. Yeung, S. W. Y. Yip and G. K K. Leung, "Surgical vision: Google Glass and surgery," Surgical innovation, 23(4), pp. 422-426, 2016.

[44] P. Kim, "Massive open online courses: the MOOC revolution," New York, NY: Taylor \& Francis, 2015.

[45] R. Andersen and M. Ponti, "Participatory pedagogy in an open educational course: challenges and opportunities," Distance Education, 35(2), pp. 234-249, 2014.

[46] M. H. Baturay, "An overview of the world of MOOCs," ProcediaSocial and Behavioral Sciences, 174, pp. 427-433, 2015.

[47] X. Chen, L. Xu, Y. Wang, H. Wang, F. Wang, X. Zeng and J. Egger, "Development of a surgical navigation system based on augmented reality using an optical see-through head-mounted display," Journal of biomedical informatics, 55, pp. 124-131, 2015.

[48] Á. Fidalgo-Blanco, M. L. Sein-Echaluce, and F. J. García-Peñalvo, "Methodological Approach and Technological Framework to break the current limitations of MOOC model," Journal of Universal Computer Science, 21(5), pp. 712-734, 2015.

[49] D. Gamage, S. Fernando, and I. Perera, "Quality of MOOCs: A review of the literature on effectiveness and quality aspects," UbiMedia Computing (UMEDIA), 2015 8th International Conference, pp. 224-229, 2015b.

[50] N. Hood, A. Littlejohn and C. Milligan, "Context counts: How learners' contexts influence learning in a MOOC," Computers \& Education, 91, pp. 83-91, 2015.

[51] M. S. Hossain, M. S. Islam, J. V. Glinsky, R. Lowe, T. Lowe and L. A. Harvey, "A massive open online course (MOOC) can be used to teach physiotherapy students about spinal cord injuries: a randomised trial," Journal of physiotherapy, 61(1), pp. 21-27, 2015.

[52] P. Lowenthal and C. Hodges, "In search of quality: Using Quality Matters to analyze the quality of massive, open, online courses (MOOCs)," The International Review of Research in Open and Distributed Learning, 16(5), 2015.

[53] N. Spyropoulou, G. Demopoulos, C. Pierrakeas, I. Koutsonikos and A. Kameas, "Developing a Computer Programming MOOC," Procedia Computer Science, 65, pp. 182-191, 2015.

[54] W. Xing, X. Chen, J. Stein and M. Marcinkowski, "Temporal prediction of dropouts in MOOCs: Reaching the low hanging fruit through stacking generalization," Computers in Human Behavior, 58 , pp. 119-129, 2016.

[55] J. Zhang, "Can MOOCs be interesting to students? An experimental investigation from regulatory focus perspective," Computers \& Education, 95, pp. 340-351, 2016.

[56] P. J. Guo, J. Kim and R. Rubin, "How video production affects student engagement: An empirical study of mooc videos. In," Proceedings of the first ACM conference on Learning@ scale conference, pp. 41-50, 2014

[57] J. Cohen, "Statistical power analysis," Current directions in psychological science, 1(3), pp. 98-101, 1992.

[58] J. Cohen, P. Cohen, S. G. West, and L. S. Aiken, Applied multiple regression/correlation analysis for the behavioral sciences, Routledge, 2013 